Loimeier, Roman (2018): India Beyond India: The Indian Diaspora in East Africa. In: Elfriede Hermann and Antonie Fuhse (eds.): India Beyond India: Dilemmas of Belonging. Göttingen: Göttingen University Press (Göttingen Series in Social and Cultural Anthropology, 12), pp. 151-172. Doi: 10.17875/gup2020-1268

\title{
8 India Beyond India: The Indian Diaspora in East Africa
}

\author{
Roman Loimeier
}

\section{Conceptual Framework}

Issues of communitarian organization, identity, and belonging have long informed the history of the subcontinent (today India, Pakistan, Bangladesh, Nepal, and Sri Lanka), and they continue to do so. Prominent examples include the muhäjirün in Karachi/Sindh, Hindu-Muslim strife in Gujarat, temple and mosque disputes in Uttar Pradesh and other regions, and ethnic conflict throughout the subcontinent. ${ }^{1}$ Communitarian organization, identity and belonging are informed by variegated historical legacies, politics, religion, social and ethnic dynamics, questions of class, and respective modes of 'othering.' The question arises, however, if such dynamics have also influenced the development of the Indian diaspora, or if questions of 'belonging' have become paramount in the context of the rise of African national states. My contribution looks into this question by focusing on the development of the Indian diaspora in East Africa and Tanzania/Zanzibar in particular. Looking at a number of Indian diasporic communities in their historical context, I ask if these communities have reproduced metropolitan (i.e. Indian) communal disputes, or if they have rather sought to find a place for themselves in colonial and postcolonial East Africa.

\footnotetext{
${ }^{1}$ For a discussion of the term 'communalism' see Peter van der Veer (1994).
} 


\section{History of the Indian Diaspora in East Africa}

Indians first arrived in East Africa in pre-recorded times, possibly more than a thousand years ago. Due to the monsoon wind system, traders who came to East Africa with the northeast monsoon (Swahili: kazkazi, from December to March), had to stay on the coast for several months until they could return to India or Arabia with the southwest monsoon (Swahili: kusi, from May to August). The monsoon wind system thus encouraged the establishment of a temporal Indian presence on the East African coast. In the $16^{\text {th }}$ century, this presence was recorded by Portuguese sources and seems to have become more permanent around this time. Indeed, the pilot 'Malemo Canaqua,' who guided Vasco da Gama straight across the Indian Ocean to Calicut in 1498, was an Indian resident of Malindi (Sheriff 2010: 110). However, it was not until the early $19^{\text {th }}$ century that Indian settlements in East Africa grew significantly and became more prominent.

The development of a permanent Indian presence in East Africa was connected to the expansion of the Sultanate of Oman in the $19^{\text {th }}$ century. Although Oman had started to intervene on the East African coast in the mid-1 $17^{\text {th }}$ century, its position there remained marginal until the early $19^{\text {th }}$ century, when the Bū Sa'i ì ì dynasty in Masqat realized the coast's economic value and shifted the seat of the government to Zanzibar in 1840 (see Sheriff 1987). In 1804, the Sultan of Oman had started to 'farm out' control of Zanzibar's customs to, amongst others, Indians ('Banians,' i.e. Hindus), who paid the Sultan an annual fee for the license to collect customs fees. ${ }^{2}$ In 1818/1819, the (Hindu) Indian trader Jairam Sewji took over the lucrative position. In 1837, the Jairam Sewji family also took control of customs on the Mrima coast opposite Zanzibar. Sewji's company retained control over Zanzibar's customs until 1886, when Sultan Barghash established a government customs department (Sheriff 1987: 84,127$){ }^{3}$

In 1839, a British-Omani commercial treaty allowed British subjects (including Indians from those parts of India already under British legislation) to enter Zanzibar, and to reside and trade within the Sultan's dominions along the East African Coast (Oonk 2006: 254ff). Trade subsequently increased, as did the number of Indians on the coast, from 214 in 1819 to 2,500 in 1870, and to 6,000 in the early 1900s. The immigrants were mostly poor Muslims from Gujarat, especially from the Kutch peninsula, and were typically small shop owners, small scale traders, and craftsmen. Trading and entrepreneurial families such as the Topans, the Visrams and the Parroos even became financiers of Arab slavers. However, the major trade item was African

\footnotetext{
${ }^{2}$ As a result of this policy, the Indian community in Zanzibar had grown to 214 persons by 1819, "and they were already described as wealthy" (Sheriff 2016: 3).

${ }^{3}$ In 1876 however, another wealthy Indian trading family, that of Tharia Topan, managed to outbid the Sewji Company by offering an annual fee of 450,000 Maria Theresien Thaler (MTT) for the right to collect custom duties. In 1880, the Jairam Sewji family was able to regain control over Zanzibar's customs by outbidding the Topan family with an annual payment of 500,000 MTT (Bennett 1978: 106).
} 
ivory, which was highly sought after in India, where it formed an important part of dowries. In addition, Indian traders bought spices, copal, cloves, goat skin, and dried fish. The major import from India was so-called 'Surat cloth,' various textiles which came primarily from Surat in Gujarat.

From the beginning, the Indian community in East Africa was characterized by social and religious fragmentation. Three criteria informed the formation of local communities: religion, regional origin, and occupation. Most Hindus, for instance, were Bhatias, Vanias and Lohanas, ${ }^{4}$ who came as merchants, traders, and brokers from Kutch, whereas Patels came from an agricultural background in central Gujarat. Other Gujarati Hindus belonged mainly to artisan groups, whereas Punjabi immigrants were less informed by social origin, forming a single community in East Africa. Community development was particularly informed by the development of different religious orientations in East Africa. Despite Hindu's pioneering the early trade, Muslims soon came to dominate the Indian diaspora in East Africa. A first Khōja-Ismā'îlī Jamā'at Khāna (community center) was established as early as 1838 in the Forodhani ward in Zanzibar. ${ }^{5}$ The Khōja-Ismāeili ì community included prominent members such as Tharia Topan (1823-1891) and the trader Allidina Visram (1851-1916), who all became important to funding the community's social activities. The Khōja-Ismāî̀līs mostly came from Kutch/Gujarat (like most other Indians in East Africa), as well as from Punjab and Sindh (Daftary and Hirji 2008: 204206). The development of the Khōja-Ismāîlī group parallels that of the Bohora community ${ }^{6}$ and other Indian families that were dominated by rich traders, like those of Sewa Haji (1851-1897) and Nasser Veerjee (1865-1942). The most prominent Bohora family was the Karimji-Jivanji family, which came from the Kutchi seaport Mandvi to Zanzibar in 1818, and opened its first business in 1825 . $^{7}$ From modest beginnings, the Karimji family became one of the richest Indian families in East Africa, involved in all kinds of trade, as well as sisal and cashew production. Nearly 150 years later, the Karimji-Jivanji family would become the East African representatives for Toyota (and also for Tata and Chrysler). Like other wealthy Indian families, the Karimji family engaged in charitable activities.

From the 1890s, the number of Indian indentured workers or 'coolies' (who came primarily from Punjab) increased, while Goans started to be recruited as civil

\footnotetext{
${ }^{4}$ Lohanas are a Kshatriya group, often administrators, and are also traders today. Most Khojas are Lohana by origin; Vanias and Bhatias are comparatively small high caste groups from Rajasthan.

5 The Khōja-Ismāeilīs represent the Nizārī-branch of the Ismā'illiyya. The Ismā'iliyya are the 'sevener' branch of the Shí'a in contrast to the 12'er or Ithnā'sharī branch. The present Aga Khan is the $49^{\text {th }}$ religious leader of the Khōja-Ismā'ìlīs. For a history of the Khōja-Ismāīìi community see Daftary and Hirji (2008).

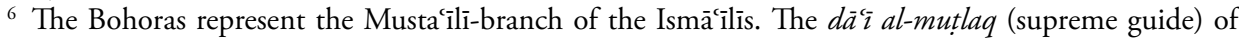
the Bohoras has been Sayyid Muhammad Burhānuddīn since 1965. He is the $52^{\text {nd }} d \bar{a}^{-} \bar{\imath}$ al-mutlaq of the Bohoras. His father, Sayyid Ṭāhir Saifuddinn directed the Bohora community from 1915 until his death in 1965. For a history of the Bohora community see Blank (2001).

7 The history of Karimji-Jivanji family has been recorded in great detail by Gijsbert Oonk (2009).
} 
Table 1: Indian population growth in four East African countries

\begin{tabular}{rrrcr}
\hline Year & Kenya & Uganda & Tanganyika / Zanzibar & \multicolumn{1}{c}{ Total } \\
\hline 1921 & 25,253 & 5,200 & $10,209 / 13,772$ & 54,000 \\
\hline 1931 & 43,623 & 14,150 & $25,144 / 15,247$ & 98,000 \\
\hline 1939 & 46,897 & 17,300 & $25,000 / 15,500$ & 104,000 \\
\hline 1962 & 175,000 & 77,500 & $92,000 / 20,000$ & 362,000 \\
\hline 1969 & 140,000 & 75,000 & 85,000 & 300,000 \\
\hline 1972 & 105,000 & 1,000 & 52,000 & 158,000 \\
\hline 1984 & 50,000 & 1,000 & 30,000 & 81,000 \\
\hline $1995 / 2000$ & 100,000 & 12,000 & 90,000 & 202,000 \\
\hline
\end{tabular}

Source: Oonk (2006: 256)

servants. The indentured workers were employed mostly on the Mombasa-Uganda railway, which was built from 1895-1903. Indeed, 35,000 coolies were brought to East Africa for this project alone. By 1914, the number of Indians had grown to 38,000 , and to 55,000 by 1921 . Although most indentured laborers left East Africa when the Mombasa-Uganda railway was completed, around 7,000 remained (mostly in Kenya) and worked as railway personnel, drivers, stationmasters, foremen, linesmen, repairmen, upholsterers, carpenters, and other artisans, while others settled down as dukka wallas (small shop owners) (Oonk 2006: 255).

The next phase of immigration started during and after WWI and was linked with the British war effort, when tens of thousands of Indian soldiers and porters brought to East Africa to fight the Germans. After WWI, a growing number of Indians found employment in the colonial administration and economy. As a consequence of Indian mass emigration beginning in the late $19^{\text {th }}$ century, ${ }^{8}$ the Brahmin idea that crossing the ocean (kala pani, 'the black water') would cause ritual impurity and even render Hindus 'outcasts,' became increasingly obsolete. A member of the Shree Shiv Shakti Mandir in Zanzibar and a Brahmin himself summarized this development in a conversation in 2010, when he told me that "the diaspora killed the idea of the black water, even Brahmins travel around the world today" (Joshi sr., 18 August 2010). By 1939, the number of Indians in East Africa had grown to 105,000. After WWII, the Indian population increased further, and by 1962, 362,000 Indians were living in the four East African countries (see Table 1 for an overview).

\footnotetext{
${ }^{8}$ During this period of mass emigration, Indians not only immigrated to East Africa but also to the Caribbean, Mauritius and Fiji.
} 


\section{The Indian Communities in East Africa after Independence}

After independence (Tanganyika in 1961, Uganda in 1962, Kenya and Zanzibar in 1963), ${ }^{9}$ East African governments gave those Indians who were not automatically citizens by birth an option to register within two years. As many Indians hesitated to apply for citizenship, administrations took "their procrastination as an expression of a lack of faith in these states" (Oonk 2006: 258) and started to introduce periodic embargoes, which again increased suspicion among Indians. However, some Indian group leaders, especially those from the Khōja and Bohora Ismāîlīis, encouraged their members to apply for citizenship. In 1952, the Aga Khan (the religious leader of the Khōja Ismā̄îlis) advised his followers to regard East Africa as their permanent home, to speak English rather than Gujarati, and encouraged women to wear Western dress (Oonk 2006: 261). ${ }^{10}$

Despite the willingness of the Aga Khan to cooperate with East African governments, national politics quickly led to conflict. One of the first victims of Tanganyika (from 1964 Tanzania) President Nyerere's policies to marginalize and even eliminate old elites was the East Africa Muslim Welfare Society (EAMWS), a supranational Muslim welfare organization dominated by Indians as well as some conservative African religious scholars such as Hasan b. 'Ameir. The EAMWS had been founded in 1937 by the Aga Khan. Since 1961, its headquarters had been in Dar es Salaam. In the context of emerging nationalisms in East Africa, the EAMWS that had propagated Muslim unity became increasingly obsolete and was dissolved in 1968 (see Loimeier 2007). The 1967 Arusha declaration started a period of anti-Asian' (i.e. anti-Indian) policies in all three East African countries. These policies included the nationalization and expropriation of Indian businesses, properties and houses, and triggered waves of Indian emigration from all East African countries. The most brutal policies were applied in Zanzibar, where many Indians were killed in the revolution of January 1964 or subsequently fled; and in Uganda in 1972, where 70,000 Indians had to leave the country within 90 days (see Oonk 2006: 259). In Tanzania, the Nationalization of Buildings Act of 22 April 1971 (Oonk 2009: 105) led to an Indian exodus, and to the effective expropriation of the Karimji and other wealthy 'Asian' families' property. Between 1964 and 1972, 40-50\% of all Indians in Kenya and Tanganyika emigrated to the USA, Canada, and Britain (Oonk 2006: 254ff), forming a diaspora of 'twice displaced' Indians. In the 1980s, governments across East Africa revised their anti-Indian policies. In Uganda, President Museveni even ordered the return of confiscated properties to their former Indian owners. Still,

\footnotetext{
${ }^{9}$ In 1964, Zanzibar and Tanganyika united and formed the Federal Republic of Tanzania.

10 This policy was rejected by the déa $\bar{c}$ al-mutlaq of the Bohoras. The Bohoras opposition to integration backfired in 1968, when the Tanzanian government expelled the déc al-mutlaq Sayyid Muhammad Burhānuddīn for allegedly violating foreign exchange regulations. The dēi $\bar{\imath}$ al-mutlaq had been visiting the Bohora communities in Tanzania to bring them into closer compliance with the policies of the Bohora dä'wat (the 'message') (Blank 2001: 240).
} 
anti-Indian sentiment remains vibrant, and anti-Indian riots and occasional protests occur in all East African countries, especially in Uganda and Kenya.

In Tanzania, governments from Ali Hassan Mwinyi (1985-1995) through Benjamin Mkapa (1995-2005) to Jakaya Kikwete (2005-2015) have encouraged Indians to return and presented them as the 'saviors' of the Tanzanian economy (Oonk 2006: 260). With economic liberalization starting in Tanzania in 1985, many Indian families indeed began to rebuild business, albeit cautiously. Yet by 2010, the Indian community in Tanzania had grown to about 200,000 (Kaid Lookmanji, 7 August 2010), and even small provincial towns such as Iringa again had their own Indian Muslim and Hindu communities. By 2010, Dar es Salaam alone had 15,000 Hindus and at least ten major Hindu temples, mostly situated in or near Kisutu Street (9 temples), i.e. in the center of the Uhindini ('Indian') ward of central Dar es Salaam, and in Upanga ( 1 temple). These temples catered for different religious orientations among the Hindus, as well as for Hindus from different regions of origin in India (Gujarat, Maharashtra, Konkan etc.). There were also temples devoted to specific gods such as Rama, Shiva, or Krishna. In addition, the Hindu community in Dar es Salaam managed one 'Hindu' hospital, the 'Shree Shiv Shakti Hospital,' as well as a library and a gym. ${ }^{11}$

\section{Indians in Pre-Colonial Zanzibar}

In the $19^{\text {th }}$ century, Zanzibar's economy boomed under the Sultanate of Oman's liberal trade policies. The boom led to considerable population growth. In 1819, Zanzibar Town had a population of about 5,000 inhabitants, but by 1835 it had doubled or even tripled. By 1846, it had grown to about 20-25,000, and by 1885 had reached about 80,000 (Bennett 1978: 57; Sheriff 1987: 138). Zanzibar's population not only grew but also became increasingly diverse. By the 1840s, 5,000 Omanis and between 400 and 700 Indians had settled. By the 1870s there were about 3,000 Indians (mostly Gujaratis) living in Zanzibar, including 2,000 'Banians' (Indians belonging to different Hindu orientations and occupational groups). ${ }^{12}$ Most Indians settled in the Kiponda, Hamamni, and Kajificheni wards and built representative houses, whereas poor Indians settled in Ng'ambo, the 'other side' of the 'creek' that separated the old town from the rural areas (see Sheriff 1992 and 1995). In addition, there were Hadrami and Yemeni communities, immigrants from Madagascar, the

\footnotetext{
11 Since 2005, an 'Indian' building boom has led to the destruction of many old buildings in the Uhindini quarter in Dar es Salaam. This building boom was linked with the fact that leases on plots of land in 'Uhindi' that had been granted by the British colonial administration in the mid-1930s expired in the mid-2000s. Indian lessees were thus able to buy 'their' plots and started to replace the old two- or three-storey buildings with new buildings that were much larger (my own observations, 11 August 2010).

12 There were also some Zoroastrians, mostly from Bombay. They were allowed to establish their own 'fire temple' in Zanzibar in 1882 (Exhibition, House of Wonders).
} 
Comoros and Somalia (particularly from the Brāwa region), indigenous Zanzibaris, Wapemba, Watumbatu, and the 'Hadimu' people from Zanzibar's east coast, as well as Africans from the hinterland stretching back as far as Manyema (Eastern Congo), Baluchis from south-eastern Iran, and a growing community of Europeans (Sheriff 1987: 147, 149).

The $19^{\text {th }}$ century was thus characterized by the development of a polyphonic society in Zanzibar Town that stressed social criteria as markers of distinctness: being an aristocrat or a slave was more important than being 'white' or 'black.' Even the Sultan's family was divided into an 'Abyssinian' and a 'Circassian' line (see Ruete 1998: 85ff). Intermarriage and concubine (suria) relationships led to the emergence of a large group of 'black' Arabs (Africans who came to regard themselves as 'Arab' due to their affiliation with an Arab family). The Indians in Zanzibar, by contrast, mostly refused to intermarry with Africans, yet many men maintained suria relationships with African women. The refusal to intermarry thus became a major obstacle to Indian integration in East Africa. Indians not only refused to marry non-Indians, but maintained practices of exclusion and social avoidance among themselves. There were, however, a few exceptions: Ithnā'sharī communities' marriage practices were less exclusive; some early migrants from Surat mixed with the African population in Zanzibar in the early $19^{\text {th }}$ century; and Hindu migrants, who were predominantly male until the late $19^{\text {th }}$ century, seem to have had African concubines more frequently (see Sheriff 1987 and Issa 1995).

The emerging Indian community in Zanzibar was split into numerous different fractions. In 1870, the Indian Muslim community consisted of three major groups: the Khōja Ismāîilis, the Bohoras and the Memons, a small Sunni (Hanafī) group. In 1870, there were less than 250 Memons, mostly from Gujarat (Kathiawar and Kutch regions), usually Surat and Porbandar, or from Lohanpur in Sindh (Martin 1978: 34-5). The Khōja-Ismā'îlī community was the largest group with 535 families in 1870, 422 of them originating from Kutch. About 2,100 people belonging to this group had their permanent residence in Zanzibar, while the other 450 members settled on the mainland. The Bohora community, another branch of Ismā'îlī orientation, was the second largest. Most of them originated from Rajkot and Kutch. In 1870 about 250 lived in Zanzibar, while about 600 lived on the coast. Most Bohoras made a living as craftsmen, artisans, locksmiths, petty traders and ironmongers, while Khōjas were usually traders, or entrepreneurs in import-export and long-distance trade businesses. Later on, many became artisans. Memons, Bohoras and Khōjas were also marked by different social and occupational affiliations: they were either Kokni (traders from Konkan, although not all Koknis were Memon), Lohana (traders from Lohanpur, although not all Lohanas were Memon), or Bania (often regarded as Hindu traders, although some were Memon, and thus, Muslim). ${ }^{13}$ In addition, there was a small Muslim Khumbar ('Kumbaro') population of often

${ }_{13}$ Zanzibar National Archive, ZNA AB 1/36: Reconstitution of the Committee of the Sir Euan Smith Madrasa. 
itinerant petty traders who are today pot-makers in Makunduchi, as well as a small group of Catholic Indians from Portuguese Goa, and a group of about 300 Hindus (Martin 1978: 36).

This situation was further complicated by the fact that the terms 'Bohora' (as derived from the Gujarati term vohorvun, trader) and 'Khōja' as well as 'Kokni,' 'Kumbaro,' 'Bania,' or 'Lohana' did not necessarily denote religious affiliation, but could also mean an occupational and/or social group that might be Sunnī or Hindu rather than Shīì-Ismāîilī (Khōja or Bohora). Religious and/or occupational groups were finally divided by non-religious splits, sometimes seeking to legitimize these splits as socio-ethnic arguments. The Memon community in Zanzibar thus split into two communities between 1945 and 1956, ${ }^{14}$ namely the 'Hindu Sunni Kokni Jamā'at' (which became Shāfi ì) and the 'Cutch Memon Association' (which remained Hanafi). The Khōja group in Zanzibar equally split due to disputes over the political reforms started by the Aga Khan in India: the dissident Shī‘a Khōja-Ithnācshara community emerged in fact from the larger Khōja-Ismācilì-group in the course of the $19^{\text {th }}$ century, when the political and religious leader of this group (the 'Aga Khan') had to flee Iran and settled in Bombay in 1844. When he began to impose his authority over the Khōja-Ismā'îlī community there, a number of Khōja-Ismāêilīs split and established the 'Sunni-Khōja' group (in India in 1869) and the Shī'a KhōjaIthnāsshara group (in India and East Africa in 1877) (Sheriff 2016: 8). ${ }^{15}$ However, the new Ithnā'shara Khōja group refused to mix with non-Khōja Ithnā'shara Indian Muslims. Equally, the Bohora community (dä'wat, lit. 'cause') has seen splits due to the fact that the community's leadership tried to secure Bohora 'orthodoxy' with respect to other Ismā'îli-groups in both colonial and post-colonial times by practicing baraat, the social ostracism/exclusion of dissident members. Baraat, in fact, excludes dissident Bohoras from religious rituals performed by Bohora scholars, including the dāi al-mutlaq. It can amount to exclusion from the complete spiritual and social sphere, as well as the economic, educational and welfare services of the dá wat (Blank 2001: 180f). In January 1979 and June 1981 Bohora orthodoxy was stressed in a

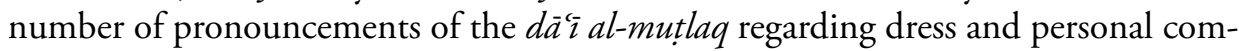
portment. Since then, Bohora women have switched to the 'typical' Bohora burqa and its rida, a bonnet which can be used as a facial veil, while men were compelled to wear a beard as a sign of Bohora identity and loyalty towards the dáci al-mutlaq (Blank 2001: 184). Communities such as the Bohoras and the Khōjas, in addition, refused to pray with other Muslims in their respective mosques and had their own Jamācat Khānas.

\footnotetext{
${ }_{14}$ Zanzibar National Archive, ZNA AB 22/51: Kokni Jamat.

${ }^{15}$ Even today members of both communities refuse to talk about the reasons for the split.
} 


\section{British Economic Policies in Zanzibar}

On 7 November 1890, Britain assumed full political control over the Sultanate of Zanzibar, making it a British Protectorate until 12 December 1963, when it became independent again (see Loimeier 2009). While Zanzibar underwent thorough political and administrative change in the colonial period, most Zanzibaris were preoccupied with economic development after 1890. Abolition in particular, which was implemented between 1890 and 1897, soon turned out to be a major problem for the British. They feared "that freed slaves would seek to be independent peasants, the clove industry would collapse, the already heavily indebted Arab landowners would become bankrupt, and the government would lose its main source of revenue" (Bakari 2001: 49). However, few slaves actually achieved emancipation. Most continued to work as contractors on the plantations of their former owners (Cooper 1980: 84ff). As tenants however, the former slaves were free to work part-time on their own plots of land, creating an increasing shortage of plantation labor. The contract system was soon abandoned in favor of a wage labor system that allowed former slaves to stay as squatters on the plantations while working. This system put increasing financial pressure on the plantation owners. Consequently, they started to hire seasonal pickers from the early 1900s. These migrant workers, often Nyamwesi from central Tanganyika, soon settled permanently (Flint 1965: 650; Cooper 1980: 92ff). The move from "slaves to squatters" (Cooper 1980), and later to wage laborers, was orchestrated by the British to prevent a shortage of labor threatening the plantation economy (Sheriff 1991: 117-123; Nisula 1999: 226).

Zanzibar's Arab plantation owners not only had to survive the abolition of slavery, which led to increasing indebtedness since they had to pay now for labor, they also had to survive economic depression, with the clove price starting to drop in the late 1920s. As a result, mortgaging of trees and land increased (Cooper 1980: 139). Many farmers lost all their trees, while others could no longer maintain their plantations and their creditors, often Indians, began to take over their properties (Cooper 1980: 142). The British authorities tried to stop the demise of the Arab plantations and the rise of an Indian creditor and landowner class by establishing the Clove Growers' Association (CGA) in 1927. The CGA provided low-interest harvesting loans, storage space and minimum selling prices to plantation owners, and was responsible for marketing the clove harvest. Its goal was to save 'Arab' plantations, as 'Arabs' and not Indians were seen as the major pillar of British rule (see Shao 1992 and Gilbert 2004). When the CGA loan-system was abolished in 1928, membership fell rapidly, and Indians continued to buy clove plantations. Consequently, Indian clove tree ownership grew from 5\% in 1922 to almost 50\% in 1933 (Turki 1987: 45). The abolition of slavery, the resulting shortage of labor, the world economic depression, and the fluctuation of the clove price, as well as the dispossession of Zanzibar's mainland dominions were instrumental in the demise of the big plantation owners. Even colonial officials started to consider the big landlords a 'spent force,' with peasantization of the clove economy seen as an alternative (Bakari 2001: 50). To 
stop the demise of the big 'Arab' plantations and the rise of Indian plantation owners, and ignoring the protests of the Indian National Association (INA), the British transformed the CGA into a government body in 1934, authorized to license clove dealers and to inspect produce. In 1937 the CGA became the sole buyer of cloves.

\section{British Racial Policies in Zanzibar}

From the late $19^{\text {th }}$ century, race and skin color became increasingly paramount in Zanzibar. The British administration was particularly concerned with questions of how to identify and treat the different members of the Zanzibari population, and introduced the concept of a 'natural hierarchy of races.' Colonial history thus has to be seen as a history of framing: the framing of societies, regions, religions, and races. Such processes of framing informed ethnic classifications and led to the construction of races in Zanzibar in colonial times and a subsequent, distinct 'racialization' of Zanzibar's public life (Purpura 1997: 163). ${ }^{16}$ Even in one of the last Department of Education (DoE) annual reports, the Protectorate was described as having been "ruled by Arab Sultans since the end of the $17^{\text {th }}$ century. The Arab and the indigenous African population is exclusively Muslim, and Islam is the official religion." 17 The dynamics of racialization again touched both public and private lives, and had lasting effects on pro-independence politics, the 1964 revolution, and beyond. The British colonial view, namely that "Zanzibar was an Arab land," for instance, was used by Zanzibar's revolutionaries to legitimize the revolution in and beyond 1964 . In their concept of colonial society, the British occupied the highest rank. As British colonial rule was based on indirect rule and consequently sought to instrumentalize the Omani ruling elite to implement its policies, Zanzibar's Arab population was second in colonial racial hierarchies. ${ }^{18}$ In 1917, Zanzibar's British Resident Pearce thus stated in his education report that the population of about 200,000 was divided into different ethnic groups. "For facility of reference," these complex ethnic and religious structures were simplified by a division of the population into three 'classes':

\footnotetext{
${ }^{16}$ British efforts to identify and frame Zanzibar's populations also became apparent in the colonialera censuses $(1910,1921,1924,1931,1948$, and 1958). From the 1930s on, census data become increasingly accurate, with the censuses of 1948 and 1958 the only two to present a detailed picture of Zanzibar's population. Later census data was also increasingly detailed with respect to issues such as religious affiliation. The 1948 census (Zanzibar National Archive, ZNA AB 33/7) thus registered 21 different religions: 'Roman-Catholic,' 'Christian,' 'protestant,' 'Hindu [so stated],' 'Brahimin,' 'Vaishya,' 'Sanatan Dharamist,' 'Ārya Samāj,' 'Islam [so stated],' 'Suni [sic] Shafi,' 'Suni [sic] Hanafi,' 'Suni [sic] Maliki,' 'Shia Ismaili Khoja,' 'Shia Ithnasherikhoja [sic],' 'Shia Bohora,' 'Shia Ibadhi,' 'Jains,' 'Sikhs,' 'Zoroastrians,' 'Buddhists,' and 'unspecified.'

17 Zanzibar National Archive, ZNA BA 5/34: Annual Report 1964.

${ }^{18}$ For a general discussion about questions of 'race' and 'identity' in colonial times, see Glassman (2000 and 2004).
} 
Zanzibar possesses a cosmopolitan population and rightly to deal with the problem of education, it is desirable to appreciate the varying interests of the races and communities involved. This diversity of population, concentrated as it is in a small area, tends to complicate the question. The Asiatic and African populations of Zanzibar may be divided into three distinct races, the members of which differ in mentality, in modes of life and in aspirations. With the exception of about 2,000 Hindus, all are Muslims, but with little religious coherence or regard for each other. The first class comprises the Arabs, who represent the aristocracy and the land owning community (c. 9,000); the second class includes the British Indian communities (c. 10,000). These people are almost exclusively commercial; they are town-dwellers, constitute the great shop keeping class, and represent powerful influences in Zanzibar; the third class comprises the 'Swahili' or the African 'negroes' settled in Zanzibar: He may or may not have a few drops of Arab blood in his veins. He represents $90 \%$ of the population, and both Arabs and Indians look down on him as an inferior person; but it should be understood that he is far superior to the pagan Negro of the mainland. ${ }^{19}$

Since the British regarded the Arabs as the ruling elite and were prepared to grant them a number of privileges, it became increasingly important for Zanzibaris to be counted and registered as Arab. This explains the rapid statistical growth of 'Arabs' in colonial times. ${ }^{20}$ Many of these 'Arabs' were not plantation owners or members of the ruling family, but petty traders and small rural shopkeepers as well as small farmers (Purpura 1997: 160). Changes in perception or self-definition may have also contributed to the growth of the 'Arab' population, as did intermarriage between Arab landlords and former slaves, which became widespread. To rise socially, parents and offspring from these marriages tended to portray themselves as 'Arab.' Another major explanation for the growth of the Arab (and Indian) population was the food rationing system in WWII, which provided preferential treatment for Arabs and Indians (Asians). These groups were entitled to rice rations, while Africans received only maize and beans, a regulation that gave birth to the slogan Njaa ndiyo ilizaa makabila haya hapa Zanzibar (famine created these tribes here in Zanzibar) (Maliyamkono 2000: 5).

Ranking below the 'Arab' population, 'Indians' came second in colonial hierarchies. And like the Arab population, the Indian communities were represented by a number of associations. The largest, the Indian (National) Association, was established in 1914 (according to Mapuri in 1910; Mapuri 1996: 12), having emerged from the Indian Merchants' Association (est. 1905) (Turki 1987: 39). Under the

\footnotetext{
19 Zanzibar National Archive, ZNA AB 1/224: 1913 report on education; emphases in original.

${ }^{20}$ In fact, Zanzibar's Arab population grew rather out of proportion in the first decades of the $20^{\text {th }}$ century. Between 1924 and 1931 the Arab share of the population rose by $38 \%$, from $8.7 \%$ to $14.2 \%$, and had risen to $16.9 \%$ by 1948 (see Prunier 1998).
} 
leadership of Seth Yusufali A. Karimji, Sir Tayabali Karimji, Tayyibali Ismailji Jivanji, Mohammed N. Jindani, Jaffer Hassin Manji, and Mulji Mathuradas, it fought for the economic interests of Indian traders and businessmen, as in the clove boycott movement of the 1930s. In politics, Indians did not feature prominently until postindependence, with few exceptions, including members of the Karimji Jivanji and Hussaynali families, who were active in the Indian National Association (INA), and Rati Bulsara, ${ }^{21}$ the editor of The 'Adal Inșäf, the major Indian paper aside from The Samachar. ${ }^{22}$ There were also smaller Indian associations, based on religious, ethnic, and occupational affiliations, but they were not politically active.

The British tried to understand and reproduce the heterogeneity of the Indian population in their racial policies. To do so, they organized the Indian communities into subgroups according to religious, ethnic, regional, and social patterns. In religious terms, the British registered Hindus, Muslims, 'Parsees' (Zoroastrians), and Catholics (from Goa). In regional terms, they identified immigrants from Gujarat, in particular Kutch and Kathiawar, as well as the town of Surat. There were also some Southern Indians, again divided into different groups. In political terms, there were the Hindoo Union, the Sikh community, the Goan community, the Zoroastrian ('Parsee') community, the Hindu Mandal (Hindu community), the Baharania Association, and the Cutch Memon Association, as well as the Kokni Jamat. This latter group was confusingly called 'Hindu Sunni,' yet, in reality was the Sunni-Shāfi î fraction of the Memon community from which it had split. ${ }^{23}$ In 1945, the British administration registered seven 'Indian' religious communities (totaling 13,025 people): the 'Hindu community' (3452), the 'Khōja-Ismāîili community' (2400), the 'Sunnī community' (i.e. Memon, the Kokni Jamat; 2313), the 'Ithnā'shara community' (2000, mostly Khōja-Ithnā'ashara), the 'Bohora community' (1377), the 'Goan community' (721, who were Portuguese subjects), and the 'Parsee community'

${ }^{21}$ Rati Bulsara (also written Rutti Balsara) was one of the few politically active Indians, working as the Indian-Parsee editor of The 'Adal Inșäf, which ran from 1948 to 1964. It was one of the leading 'Indian' papers in Zanzibar at the time, boasting Zanzibar's most sophisticated printing press. In 1957, Rati Bulsara won the 1957 Stone Town constituency seat in the first Legislative Council (LegCo) elections for the Zanzibar National Party (ZNP). He also was publicity secretary of the ZNP. In 1959, he was accused of anti-colonial propaganda and banned from publishing for 12 months (Mwongozi, 22 May 1959). In 1961, he stood again as the ZNP candidate for the Stone Town seat (see Barwani et al. 2003: 163, interview with Amani Thani). Rati Bulsara was related to Bomi and Jer Bulsara, both teachers and parents of Faruk Bulsara, who became famous as Freddie Mercury.

${ }^{22}$ Most Indian newspapers published in East Africa since the early $20^{\text {th }}$ century have been published in Gujarati. The Indian community in Zanzibar started publishing Akbbār ('News') in 1907, which later became the Sunday newspaper The Samachar, edited by Fazel J. Master. Like most papers, The Samachar stopped publishing after the 1968 revolution. In 1922, Biharlal N. Anantani founded another Sunday paper, the Zanzibar Voice, which also stopped publication in 1968. The second major paper for the Indian community was another Sunday paper, The 'Adal Insäf ('The Just and Fair'), established by Rati Bulsara in 1948.

${ }^{23}$ Zanzibar National Archive, ZNA AB 22/46: Shia Khoja Ithnasheri Community. 
(212). ${ }^{24}$ These communities tried to conserve their own identity and, for instance, insisted on their own schools for religious education (see Loimeier 2009). ${ }^{25}$

The various Shi'i groups undoubtedly presented the most difficult task for the British in their efforts to compartmentalize the population. There were at least three major affiliations: the Shī'a Khōja-Ithnā'shara community; the Shī'a Imāmī Ismāîliyya Supreme Council, i.e. those Khōja who were affiliated with the Aga Khan-led Khōja-Ismā'îlīi-(Nizarī)-group; and the Bohora-Ismāēilì community, which followed their own $d \bar{a} \bar{\imath}$ al-mutlaq. Due to the unique character of some Indian communities, like the Ārya Samāj ('Community of Nobles'), ${ }^{26}$ the British were never certain how to deal with them. In a note of the Protectorate administration of 27 March 1930, Ārya Samāj was described as such:

The Arye Samaj [sic] is not a Sect but an assembly of believers of the Vedas (Ancient Hindoo Scriptures). It does not include any member of the traditional sects (Jains, Vaisnavas, Mahtais, Sikhs) for the reason that membership of the Arye Samaj implies renunciation in any belief of 'caste.' The Aryans stand to Hindooism as Protestantism stands to Roman Catholicism. It is a movement of reformation and return to simple 'first doctrines.' In her selfpresentation, the Arye Samaj claimed to be a 'Vedic Church' that believed in the omni-presence of God, that propagates science (vidya) and that would fight against ignorance (avidya). ${ }^{27}$

\footnotetext{
24 Zanzibar National Archive, ZNA AD 7/20: Indian Education 1945.

${ }^{25}$ In 1963, Zanzibar's 'Stone Town' had 48 mosques, four Hindu and one Buddhist temple, two churches, and a Zoroastrian place of worship (see Sheriff and Jafferji 1998).

26 The Ārya Samāj movement was established by the Shivaite Swami Dayananda Saraswati (18241883 ) in Gujarat in 1875. It became an important reform movement in Northern and Western India (see van der Veer 1994: 65ff), proposing a return to the 'pure' religion of the Vedas and the rejection of all post-Vedic texts. In fact, Dayananda wanted to create "a religion of the book" (van der Veer 1994: 65) like Christianity and Islam. He thus propagated the translation of the Vedic scriptures from Sanskrit into Hindi, and Ārya Samāj "discovered in Hinduism a monotheistic god, a book, and congregational worship." This was "a substantial transformation of a set of polytheistic traditions (and led to the creation of modern Hinduism)" (van der Veer 2001: 27). Ārya Samāj became a religious community in which all religious power gravitated towards the laity (despite its stress on Brahmanical scripture and ritual). The Vedic religion was proclaimed as a rational religion of the Aryan people. Ārya Samāj also stressed the importance of modern education, fought against the Hindu pantheon and iconic worship, and even attacked the caste system: whatever caste one had, one could become a priest and officiate in the Vedic sacrifice of the Ārya Samāj (functions formerly restricted to the Brahmans) (van der Veer 2001: 52). The movement also defended the sacredness of the cow and initiated the 'Cow Protection Movement,' which had a distinct anti-Muslim undercurrent. In a structural parallel to Muslim reform movements, where reformers attacked established religious scholars' hegemonic control of scriptural interpretation, Ārya Samāj attacked the Brahmans role as the central intermediaries between the texts and the pious population.

27 Zanzibar National Archive, ZNA AB 82/683: Public holidays.
} 


\section{The Indians in Zanzibar after the Revolution of 1964}

Peace in Zanzibar was disrupted in 1964. A revolutionary rising on the morning of 12 January ousted the Sultan and Muhammad Shamte's government, which had governed Zanzibar as an independent state for less than a month, having taken power on 10 December $1963 .{ }^{28}$ Led by John Okello, the revolutionaries encountered little resistance and occupied all major strategic positions by $4 \mathrm{pm}$ (see Clayton 1981; Petterson 2002; Mrina and Mattoke 1980; Wimmelbücker 2001; as well as Loimeier 2006 and 2009). Over the following days, the revolution assumed a more organized character, with the Afro Shirazi Party (ASP) Youth League and Umma cadres ${ }^{29}$ together forming the Revolutionary Council (RC) on January 16. Nevertheless, anarchic killings in both urban and rural areas continued for some days, as did other acts of 'revolutionary violence' and abuse of power. Meanwhile, control over the revolution passed into Zanzibari hands. In Raha Leo, the new revolutionary center of Zanzibar, Karume, 'Babu,' and the other revolutionaries formed the leadership which proclaimed the first revolutionary government of Zanzibar on 24 January. By then it was clear that Okello and his group had lost their influence over the government and the Revolutionary Council. On 20 February 1964, Okello himself was deported to mainland Tanganyika (Clayton 1981: 93). Zanzibar was renamed the 'People's Republic of Zanzibar and Pemba' and a policy of nationalization was implemented. Nationalization would considerably change the social set-up of the country. The new regime soon changed established economic structures and, among other things, imposed a trade monopoly, a policy which hit Indian shop owners, who were forced to close as soon as their stock was exhausted. On 8 October 1964, the External Trade Corporation became the sole importer-exporter of all goods except cloves, which were marketed by the Zanzibar State Trading Company. On 1 November 1964, the first state shop was opened in Miembini (Martin 1978: 59, 61). The nationalization of trade and the economy, as symbolized by the creation of the Zanzibar State Trading Company, led to the collapse of the economy within a few years. From June 1971, Zanzibar relied on a system of food rationing for rice, flour and sugar, based on food cards and the central distribution of food through 27 state shops.

As a result of the revolution and its aftermath, Zanzibar's demographic structure changed decisively, not because thousands of Zanzibaris were killed in the first days of the revolution, but rather because many branded 'non-Zanzibaris' were either deported, forced to emigrate, or fled the islands as refugees over the coming years (Bakari 2001: 79). The harassment and arbitrary imprisonment of Arabs, Comorians and Indians continued into the 1970s (Clayton 1981: 124). In November 1964,

\footnotetext{
${ }^{28}$ For a history of the revolution and its aftermath see Loimeier (forthcoming).

29 The Afro Shirazi Party (ASP, led by Abeid Amani Karume) and Umma (led by Abdurrahman 'Babu') parties formed in the late 1950s and early 1960s and represented a majority of the 'African' constituency in Zanzibar. Both ASP and Umma advocated radical reforms to Zanzibar's social and economic system.
} 
350 civil servants of mostly Arab origin were detained, with similar waves of arrests following in May 1966, March 1968, and in the aftermath of an alleged coup attempt against Karume in 1969, as well as in April 1972, after Karume's assassination (see Kharusi 1967 and 1969; Lodhi, Rydström and Rydström 1979: 88). Moreover, the houses of the leading Arabs and Indians, in particular the al-Barwānī, al-Lamkī and Karimji families, were taken over by the government in February and March $1964 .^{30}$

The Indian population of Zanzibar, which had not supported the Afro Shirazi Party or the revolution, also suffered. Many Indians were killed or fled. Due to their hegemonic position in trade and business, Indians encountered widespread animosity in Zanzibar. In the countryside, Indian shop-owners and money-lenders had ruled supreme until the revolution, which African Zanzibaris used to wipe out the money-lenders and the debts they owed to them. Anti-Indian feeling had been rampant before the revolution, especially during the late 1950s zama za siasa (time of politics). In an account of life in Zanzibar, Abdul Sheriff wrote that his family often went on holiday to Jambiani on the East Coast, where he played with local children. However, when the zama za siasa came, the village children were told by their parents that they should stop playing with Indians (msicheze na hawa Wahindi) (Abdul Sheriff in Sauda Barwani et.al. 2003: 316).

In addition to massacres and harassment of 'non-Africans,' most Arabs and Indians (around 13,000) were expelled from Zanzibar in 1964. Around 8,000-10,000 Arabs eventually settled in Oman (Clayton 1981: 99), while those who stayed in Zanzibar started to redefine themselves as 'Africans.' In 1967/68 another exodus of Indians took place, as the stocks that had so far enabled the (mostly Indian) shopkeepers to sell goods on the black market were exhausted, and no change in the political or economic situation was in sight. The situation became even more precarious when Karume, who wanted to eradicate all non-African influence in Zanzibar, announced a plan to forcefully marry 'Asian' girls to Africans (Martin 1978: 70). On 6 September 1970, four girls from Indian (allegedly Persian, i.e. 'Parsee') families were taken from their families and married that day by member of the Revolutionary Council Qādị Hamid Ameir Ali (Clayton 1981: 124) to other elderly council members. At a meeting Karume declared: "In colonial times, the Arabs took African concubines without bothering to marry them. Now that we are in power the shoe is on the other foot" (Clayton 1981: 124). Those members of the girls' families who protested were beaten and deported, and a number of Indian families were forced to leave the country. Many of these families tried to flee with their daughters, and

\footnotetext{
30 The expropriation of the Karimji family's property/wealth (not only in Zanzibar but also on the mainland) in the context of the Nyerere's 'nationalization' policies in the late 1960s is documented in detail in Oonk (2009: 162-167). In Zanzibar, the family villa of Sir Tayabali Karimji was taken over by the revolutionaries and became Zanzibar's 'State Guest House.' The Karimji Hospital which had also been built by Sir Tayabali Karimji was nationalized and became the V. I. Lenin Hospital, only to be renamed Mnazi Mmoja Hospital in the 1980s (Sheriff 2016: 9).
} 
there were some cases of suicide among Indian girls (Clayton 1981: 124) ${ }^{31}$ Indeed, the forced marriages are still remembered by Indians as a traumatic time. ${ }^{32}$ The final blow for the Indian communities came on 16 March 1971, when Karume told all Asians that they had to leave Zanzibar within a year (Clayton 1981: 123). At the time, 6,000 Arabs and Asians were still living in Zanzibar. From 30 June 1971, these groups were no longer given licenses for their shops. By 1972, only 3,500 Arabs and Asians remained in Zanzibar. In total, 35,000 people had left Zanzibar between 1964 and 1972 (Martin 1978: 71). In the end, the revolution obviously led to a significant reduction of the different Indian communities. Today, Indian communities have not recovered from the revolution, the subsequent mass exodus and the restrictive economic policies of the revolutionary governments until the mid-1980s.

\section{The Indian Communities in Zanzibar Today}

Nevertheless, the Indian presence in Zanzibar continues in a number of places today. In religious terms, the two remaining temples of the Hindu community have to be mentioned, namely, the 'Shree Shiv Shakti Mandir' in Forodhani/Hurumzi (built in 1958 and opened in 1959 as a temple dedicated to Ram) and the Ārya Samāj Temple in Forodhani (completed 1906). The Jamā'at Khāna of the Khōja-Ismāêlīis in Forodhani (built in 1838, rebuilt and expanded in 1905) is still standing, as are three pre-1900 Jamācat Khānas of the Bohoras in Soko Mohogo, Kajificheni/Mkunazini (Ismailji Jivanji) and Kiponda (Mulla Abdulali Walliji). There are also the Ithnā'sharī mosques in Kajificheni/Hamamni (Hujjatul Islam, built 1894/1895), Kiponda (Kuwatul Islam, 1878) and Malindi (Matemni, 1861 by Ahmad b. Nu'man), as well as the Sunni-Hanafi-Memon community mosque and school in Kajificheni/Mkunazini (1870s). Catholic Goans also have a parish around St. Joseph's church. Finally, there are the cemeteries of the different religious communities, as well as the Hindu Crematory in Kiungani. ${ }^{33}$ The Indian communities set up most cemeteries in Vuga and the adjacent areas of Ng'ambo: the Khōja-Ismāi ìli cemetery on the seashore in Mnazi Moja, which has been largely swallowed up by the Mnazi Moja hospital grounds; the Khōja-Ithnā'sharī cemetery in Vuga (including Sheriff Dewji's family vault just behind the Taasisi building), which was established after the split

\footnotetext{
31 See also Martin on forced marriages. He writes about four 'Persian' girls who were clandestinely taken away on 28 February 1973, a year after Karume's assassination. Their flight took them by dhow to the mainland, then across the Kenyan border to Mombasa, and from there via Karachi to Teheran (Martin 1978: 70-71).

32 Bohoras maintain they were particularly lucky, as they had expatriated their girls to the mainland in time. Bohoras also claim that Bohora women started to dress in a particularly unfashionable 'Bohora' style dress (burqa and rida). This is a false memory, though, as the déa $\bar{i}$ al-mutlaq first introduced the new Bohora dress for women in 1979 (Blank 2001: 184).

${ }^{33}$ Hindus believe their dead have to be cremated and the ashes scattered in a river or the sea. Thus, they established their ghat (crematory) in Kiungani, which is close to the ocean (see Issa 1995: 75).
} 
of the group from the Khōja-Ismā'îlīs in 1877; the Bohora cemetery situated in Kikwajuni, close to the former House of Representatives; the Sunni-Hanafi-Memon graveyard on the Kilimani Road, which is opposite the old Golf Course and near the 'Parsee' cemetery on Ziwani Road; the larger Khōja-Ithnā'sharī graveyard in Michenzani/Raha Leo (Issa 1995: 68/69); and the ('mainstream') Ithnā'sharī cemetery in Mwembeladu/Ng'ambo (Penrad 1995).

Indians also retain a significant economic presence, with a number of retail, textile, stationary, book and copy shops; major hotels, in particular, those linked with the Aga Khan Foundation (Serena); the Silk Road, Radha Food House, and Maharaja restaurants; at least one barber shop and one dhobi (laundry); antiques shops in Gizenga and Kenyatta Road (Zanzibar Gallery, Memories of Zanzibar, Lookmanji); Goan shops (photo-studios in particular, the Capital Arts Studio; tourist equipment, electronic); tour operators (such as Mitu), the Madrasa Resource Centre in Malindi; ${ }^{34}$ and the derelict Shree Vanikmahajan Union Hall in Kajificheni, which was built in 1957. However, the communities remain relatively small. In 2010, there were around 1,400 Indians, including about 400 Bohoras, 300 Khōjas, 400 Hindus, 200 Ithnā'sharīs, 50 Goans, some Sikhs and Memons, as well as a few Zoroastrians. In 1964, Zanzibar's Indian population had been 17,000 (Kaid Lookmanji. 7 August 2010, Vishwas Joshi, 6 August 2010, Abdul Sheriff, 18 August 2010; Zahir Bhalloo and Iqbal Akhtar, 4 August 2010).

The contemporary home of the Hindu community in Zanzibar is the Shree Shiv Shakti Mandir in Hurumzi, which was built for a community of 4,000 Hindus in Zanzibar in the late 1950s. Between 1964 and 1968, however, most Hindus fled to Dar es Salaam (Joshi sr., 2 August 2010). In Zanzibar, the Hindu community remains linked with the group of the 'Shirdi' Sai Baba in India, ${ }^{35}$ and can be called 'Shivaist' in orientation. Recently, the temple in Zanzibar was taken over by a new Brahmin priest from Mombasa, as the old priest had fled with the temple's money. The new priest introduced stricter temple discipline and excluded women from entering the inner sanctuary of the Shiva shrine. He also led the daily rituals and prayers which were recited in Gujarati. Gujarati and English were also the accepted languages in the Ārya Samāj temple, although prayers there were recited in Sanskrit. The Ārya Samāj group in Zanzibar was established in 1904 by Gokaldas Sunderji Robanath, who had come to Zanzibar at the age of nine, establishing the Ārya Samāj temple and the Ārya Kanya Vidyalaya (Girls' School) in 1906. He left Zanzibar after the revolution and died in Britain in 1967. In 2010, the Ārya Samāj community was rather small, with

\footnotetext{
${ }^{34}$ Like many other projects in Zanzibar, the Madrasa Resource Centre was also financed by the Aga Khan Foundation. The foundation can thus be seen as a transnational body seeking to exert influence on national policies by representing Khōja-Ismā'îlī interests.

35 The Shirdi Sai Baba (the 'holy father from Shirdi,' c. 1838-1918) settled as a guru and yogi in Shirdi near Bombay in 1856. His true name is unknown, he refused to answer questions about it. He tried to reconcile Hindus and Muslims. Today, a number of gurus such as the Sathya Sai Baba (b. 1926) claim to be re-incarnations of the Shirdi Sai Baba.
} 
ten to twenty members gathering for prayers on Saturday after $5.30 \mathrm{pm}$ (my own observations, 20 August 2010).

\section{Conclusion}

The diaspora in East Africa illustrates that the four dominant issues of Indian communalism, namely, regional and social descent (caste, $j a t i),{ }^{36}$ occupation and religion continue to define the development of the Indian communities. Gujaratis do not mingle with Punjabis, nor Goans with Sindhis; equally, Muslims keep their distance from Hindus and vice versa (as do Christians). Even among Muslims, 'sectarian' orientations prevail, especially among the different Shī'ī groups. Finally, social origin and occupational background continue to inform everyday interaction and reinforce religious and regional identities. The divide between Khōjas and Bohoras - a divide even within the Ismāîliyya - corresponds to a divide between higher-ranking Lohanas (Khōjas) and lower-ranking Bohoras, who were often craftsmen, artisans, locksmiths, petty traders, and ironmongers when they came to East Africa. ${ }^{37}$ The longevity of communal divisions amongst Indians in East Africa is remarkable as it runs against an argument implicit in the academic literature on migration and diaspora: namely, that outside pressure, crisis and oppression directed against a specific ethnic/religious and/or social group reduces or even prevents conflict among minorities who wish to defend themselves in an inimical environment. The history and development of the Indian communities in East Africa shows, however, that fragmented communities may remain fragmented even under conditions of duress. At the same time, in postcolonial times Indian communities have come under serious pressure to either 'quit' or 'conform' by integrating themselves into East Africa's new nation states. However, the pressure on Indians to commit themselves completely to a new identity and to become exclusively 'Kenyan' or 'Tanzanian' was unacceptable to most, not only because it was linked with the forced nationalization of property, but also because it would have meant abandoning identification with two important 'cosmopolitan' legacies, namely the British Commonwealth ${ }^{38}$ and the Indian diaspora worldwide and its roots in India (and, to a lesser degree, Pakistan).

\footnotetext{
${ }^{36}$ I define 'caste' here as a basic concept of social organization that is informed by occupational functions and a ritual division of work. 'Castes' unite persons and groups that are linked by bounds of blood and consequently stress endogamous marriage. The true character of a specific 'caste' can be identified only in relationship and contrast to other 'castes' that are linked to each other in social, political, religious and economic terms (see Michaels 2006: 176/177, 184).

37 As the poorest Indian community in Zanzibar, the Bohoras suffered significantly less in the revolution and its aftermath than Ithnā'sharīs and Khōjas. Indeed, the Bohoras were even able to take over some of the business of the other Indian groups, especially the Khōjas, in the 1980s. As a result, many Bohoras have become traders and shop-owners and dominate these businesses today, even more than Khōjas did before 1964. To a certain degree, this is also true for the Tanzanian mainland.

${ }^{38}$ Most Indians in East Africa had a British passport and were rather unwilling to exchange these for
} 
The fragmented character of the Indian diaspora in East Africa extends to Zanzibar, where duress has been even more severe than in other parts of East Africa (with the exception of Uganda in 1972). Despite virtually collapsing after the revolution and not having recovered today, Indian groups in Zanzibar still maintain communal exclusivities and refuse to intermarry with other Indian groups or non-Indians. Equally, political oppression has made integration into post-revolutionary Zanzibar virtually impossible for Indians, and has consequently prevented them from developing an idea of 'belonging' to the nation. The established patterns of non-intermarriage practiced in India thus remain current in both East Africa and Zanzibar. Clearly, communal issues prevail and are not about to be dissolved in the foreseeable future. Even in Zanzibar, which has a tiny Indian population today, there is nothing like a homogeneous Indian community. Indians are rather split into different fractions and distinct communities that reject intermarriage, even if there are no open conflicts.

\section{Acknowledgements}

I would like to express my gratitude to a number of Zanzibari 'Indian' friends and colleagues who have supported me in my research. In particular, Professor Abdul Sheriff, formerly of the Department of Archives, Museums and Archaeology in Zanzibar and former Director of the Zanzibar Indian Ocean Research Institute (ZIORI); Yunus Sameja, the owner of an Islamic bookshop in Darajani; the owner of the Capital Arts Photo-Studios; my dhobi (laundryman) in his Shree Ramji Laundry in Soko Mohogo; the new priest of the Shree Shiv Shakti Mandir (the 'Temple of the most respected Lord Shiva') in Hurumzi as well as Joshi sr. and his son Vishwas Joshi; Kaid Lookmanji, a Bohora trader and owner of an antiques shop in Gizenga who let me live in his old family house in Kajificheni; as well as Mufaddal A. Karimji, the owner of the Hatimi-copy shop in Mkunazini, where I have done most of my copying since 2001 .

new Ugandan, Kenyan, or Tanzanian passports. When ethnic cleansing (as in Uganda and Zanzibar) or the nationalization of Indian properties (as in Kenya and Tanganyika) started, East Africa's Indians found it relatively easy to migrate to Commonwealth countries such as Great Britain and Canada. Canada, especially the federal states of Alberta (Edmonton) and Ontario (Toronto), became a new centre of 'twice displaced' Indians. 


\section{References}

Bakari, Mohammed A. 2001. The Democratisation Process in Zanzibar: A Retarded Transition. Hamburg: Institut für Afrika-Kunde.

Barwani, Sauda A., Regina Feindt, Ludwig Gerhardt, Leonhard Harding, and Ludger Wimmelbücker, eds. 2003. Unser Leben vor der Revolution und danach - Maisha yetu kabla ya mapinduzi na baadaye: Autobiographische Dokumentartexte sansibarischer Zeitzeugen. Köln: Köppe.

Bennett, Norman R. 1978. A History of the Arab State of Zanzibar. London: Methuen.

Blank, Jonah. 2001. Mullahs on the Mainframe: Islam and Modernity among the Daudi Bohras. Chicago: University of Chicago Press.

Clayton, Anthony. 1981. The Zanzibar Revolution and its Aftermath. London: Hurst.

Cooper, Frederick. 1980. From Slaves to Squatters: Plantation Labor and Agriculture in Zanzibar and Coastal Kenya 1890-1925. Nairobi: Kenya Literature Bureau.

Daftary, Farhad, and Zulfikar Hirji. 2008. The Ismailis: An Illustrated History. London: Azimuth Editions.

Flint, J. E. 1965. “Zanzibar 1890-1950.” In History of East Africa. Vol. 2, edited by Vincent Harlow, E. M. Chilver, and Alison Smith, 641-71. Oxford: Clarendon Press.

Gilbert, Erik. 2004. Dhows and the Colonial Economy of Zanzibar, 1860-1970. Oxford: James Currey.

Glassman, Jonathon. 2000. "Sorting out the Tribes: The Creation of Racial Identities in Colonial Zanzibar's Newspaper Wars." Journal of African History 41 (3): 395-428.

- 2004. "Slower Than a Massacre: The Multiple Sources of Racial Thought in Colonial Africa." American Historical Review 109 (3): 720-54. doi:10.1086/530553.

Issa, Amina A. 1995. "The Burial of the Elite in Nineteenth-Century Zanzibar Stone Town." In The History and Conservation of Zanzibar Stone Town, edited by Abdul Sheriff, 67-81. London: James Currey.

Kharusi, Ahmed S. 1967. Zanzibar: Africa's First Cuba: A Case Study of the New Colonialism. Richmond: Foreign Affairs Publishing.

- 1969. The Agony of Zanzibar: A Victim of the New Colonialism. Richmond: Foreign Affairs Publishing.

Lodhi, Abdulaziz Y., Anette Rydström, and Gunnar Rydström. 1979. A Small Book on Zanzibar. Stockholm: Författares Bokmaskin.

Loimeier, Roman. 2006. "Memories of Revolution: Zur Deutungsgeschichte einer Revolution." Afrika Spectrum 41 (2): 175-97. http://nbn-resolving.de/ urn:nbn:de:0168-ssoar-104576. 
—_ 2007. "Perceptions of Marginalization. Muslims in Contemporary Tanzania." In Islam and Muslim Politics in Africa, edited by Benjamin F. Soares and René Otayek, 137-56. New York: Palgrave Macmillan.

- 2009. Between Social Skills and Marketable Skills: The Politics of Islamic Education in 20th Century Zanzibar. Leiden: Brill.

1964 Revolution in Zanzibar." In Social Memories and the Zanzibar Revolution, edited by William Bissell, Marie-Aude Fouéré, and Martin Walsh. Dar es Salaam: Mkuki na Nyota Publishers.

Maliyamkono, T. L., ed. 2000. The Political Plight of Zanzibar. Dar es Salaam: Tema Publishers.

Mapuri, Omar R. 1996. Zanzibar. The 1964 Revolution. Achievements and Prospects. Dar es Salaam: Tema Publishers.

Martin, Esmond B. 1978. Zanzibar: Tradition and Revolution. London: Hamilton.

Michaels, Axel. 2006. Der Hinduismus: Geschichte und Gegenwart. München: Beck.

Mrina, B. F., and W. T. Mattoke. 1980. Mapambano ya Ukombozi Zanzibar (The Struggle for Liberation in Zanzibar). Dar es Salaam: Tanzania Publishing House.

Nisula, Tapio. 1999. Everyday Spirits and Medical Interventions: Ethnographic and Historical Notes on Therapeutic Conventions in Zanzibar Town. Saarijärvi: Gummerus Kirjapaino Oy.

Oonk, Gijsbert. 2006. "East Africa." In The Encyclopedia of the Indian Diaspora, edited by Brij V. Lal, 254-61. Honolulu: University of Hawai'i Press.

- 2009. The Karimjee Jivanjee Family: Merchant Princes of East Africa 1800-2000. Amsterdam: Pallas Publications.

Penrad, Jean-Claude. 1995. "The Social Fallout of Individual Death: Graves and Cemeteries in Zanzibar." In The History and Conservation of Zanzibar Stone Town, edited by Abdul Sheriff, 82-90. London: James Currey.

Petterson, Donald. 2002. Revolution in Zanzibar: An American's Cold War Tale. Boulder: Westview.

Prunier, Gérard. 1998. “La révolution de 1964.” In Zanzibar aujourd'hui, edited by Colette Le Cour Grandmaison and Ariel Crozon, 95-112. Paris: Karthala.

Purpura, Allyson. 1997. "Knowledge and Agency: The Social Relations of Islamic Expertise in Zanzibar Town." PhD dissertation, City University.

Ruete, Emily. 1998. Memoirs of an Arabian Princess from Zanzibar: An Autobiography. Zanzibar: Gallery Publications.

Shao, Ibrahim F. 1992. The Political Economy of Land Reforms in Zanzibar: Before and after the Revolution. Dar es Salaam: University Press.

Sheriff, Abdul. 1987. Slaves, Spices and Ivory in Zanzibar: Integration of an East African Commercial Empire into the World Economy, 1770-1873. London: James Currey. 
. 1991. “The Peasantry Under Imperialism 1873-1963.” In Zanzibar Under Colonial Rule, edited by Abdul Sheriff and Ed Ferguson, 109-40. London: James Currey.

- 1992. "Mosques, Merchants and Landowners in Zanzibar Stone Town." Azania: Archaeological Research in Africa 27 (1): 1-20. doi:10.1080/0067270 9209511428.

- ed. 1995. The History and Conservation of Zanzibar Stone Town. London: James Currey.

- 2010. Dhow Cultures of the Indian Ocean: Cosmopolitanism, Commerce and Islam. London: Hurst.

- 2016. Migration and Creation of New Societies: A Story from the Indian Ocean. Zanzibar.

Sheriff, Abdul, and Javed Jafferji. 1998. Zanzibar Stone Town: An Architectural Exploration. Zanzibar: Gallery Publications.

Turki, B. S. 1987. "British Policy and Education in Zanzibar, 1890-1945."

$\mathrm{PhD}$ dissertation, University of Exeter.

van der Veer, Peter. 1994. Religious Nationalism: Hindus and Muslims in India.

Berkeley: University of California Press.

- 2001. Imperial Encounters: Religion and Modernity in India and Britain. Princeton: University Press.

Wimmelbücker, Ludger. 2001. "Die sansibarische Revolution von 1964: Widersprüche und Unzulänglichkeiten offizieller Geschichtsdeutung." In Afrikanische Beziehungen, Netzwerke und Räume, edited by Laurence Marfaing and Brigitte Reinwald, 295-308. Münster: LIT. 